\title{
GRAMMATICALISATION AND PREVERBS
}

\author{
TAMÁS FORGÁCS
}

\begin{abstract}
The aim of this paper is to investigate the historical process whereby preverbs came into being in Hungarian: to shed light on the reason why certain adverbial elements, used autonomously at first, were subsequently degraded into items of a bound grammatical category. It will be seen that that path is anything but straight: various factors may be involved in adverbial modifiers turning into preverbs, diverse "access roads" may lead to the same main road (this is also part of the reason why a number of items in the present-day stock of Hungarian preverbs are related to several parts of speech, e.g., to adverbs and to postpositions, at the same time). The second part of the paper tries to answer the questions why the stock of preverbs is presented in a heterogeneous manner in certain grammars of Hungarian, what role subjective criteria play in classifications, and how reliable the criterion of productivity is as a general guiding principle.
\end{abstract}

\section{The historical process of the emergence of preverbs}

It is common knowledge that widely divergent views can be found in the literature concerning the size of the stock of Hungarian preverbs, i.e., the number of items that can be classified as preverbs in this language (cf. e.g., Jakab 1976, 3-10; Komlósy 1992, 494-8; Kiefer-Ladányi 2000, 4802). Nevertheless, there seems to be general consensus on the view that preverbs mainly go back to adverbs (several of them are still used as adverbs and/or as postpositions today). As far as the actual manner of their emergence is concerned, however, significant differences are assumed to exist among the various subclasses of preverbs.

Pais $(1959,183-4)$ distinguishes three basic ways in which preverbs may have emerged, the first two of which, in my view, can be collapsed as in (a) below:

(a) In the first type, in addition to the adverb that will turn into a preverb, the sentence contains another adverbial constituent in an appositive relation with it; as time goes by, the adverb "changes sides" and goes over to the verb to become its preverb. 
(b) The second type is similar except that the item that "changes sides" is not an independent adverb behaving as a free morpheme but the postposition of a postpositional phrase.

(c) I think there is also a third way of preverb formation: here, two constituents of an idiomatic construction fuse into a compound that becomes the model for a productive rule of compound formation while its anterior constituent gradually turns into a preverb.

Let us take a closer look at those three types.

\title{
1.1. Preverbs from appositive constructions
}

1.1.1. As was mentioned above, this type may occur in two versions. The first version is described by Pais $(1959,183)$ as follows:

\begin{abstract}
"A considerable part of what are called independent adverbs or adverbs proper are by no means primarily independent in a 'historical' perspective. Items like alul 'underneath', felül 'on top', belül 'inside', kivül 'outside', elül 'in front', hátul 'at the back', hátra 'to the back', oldalt 'at the side', közbül 'in between', közel 'nearby', etc. did not and still do not have a meaning on their own, isolated from a given situation; it is the circumstances of speaking that lend them some concrete meaning component. Thus we can say that the adverbs at hand only gain some sense if they become related to an overt or covert item like ház 'house', kert 'garden', akol 'sheep-fold', kút 'well', barlang 'cave', fészek 'nest', terv 'plan', or rather the concepts they stand for. As a consequence, some adverbs may become replacements of an adverbial noun phrase referring to some concrete concept or else the repetition of the latter, subsequently or previously, for the sake of emphasis. For instance: Kinn a ménes, kinn a pusztán 'The herd of horses is outside, out in the wasteland'. Or: Az udvaron kinn találtak rá 'He was found outside, in the yard'."
\end{abstract}

In this case, then, the adverb having a vague conceptual content is complemented by an adverbial noun phrase having a concrete meaning; and as time goes by, the preverbal adverb (proto-preverb) loses its independence and becomes an anterior constituent of a compound, or a preverb. The most important reason of its emergence must be the pragmatic pressure mentioned by Langacker (1977) that stems from the speaker's strive for informativity and expressiveness. Pais (1959) only mentions the two examples cited above, but some early documents of Hungarian contain sentences in which it is actual proto-preverbs that stand before the verbs. Although the intonation of these sentences is unknown, if it is the case that spelling as two words reflects the competence of the language users 
of the time, the following cases exemplify the appositive-like use referred to by Pais:

\begin{tabular}{|c|c|c|}
\hline (a) & BécsiK. 5: & $\begin{array}{l}\text { le } \quad \text { vlo } \quad \text { Ruth az azatoc oldalahoz } \\
\text { down sit-past Ruth the harvester-pl side-3sg-allative } \\
\text { 'Ruth sat down at the side of the harvesters' }\end{array}$ \\
\hline (b) & MargL. 11: & $\begin{array}{l}\text { le fekzÿk vala ... egy gekenre } \\
\text { down lie-past-3sg a mat-sublative } \\
\text { 'he lay down onto a mat' }\end{array}$ \\
\hline (c) & ÉrdyK. 509: & $\begin{array}{l}\text { ffel yle lowa hathara } \\
\text { up sit-past-3sg horse-3sg back-3sg-sublative } \\
\text { 'he mounted [sat up on the back of] his horse' }\end{array}$ \\
\hline (d) & JordK. 146: & $\begin{array}{l}\text { be kelnek Emathba } \\
\text { in go-3pl Hamath-illative } \\
\text { 'they go into Hamath' }\end{array}$ \\
\hline (e) & ÉrdyK. 46: & $\begin{array}{l}\text { kywe ees kelhet belole } \\
\text { out and rise-can it-elative } \\
\text { 'he can also rise from it' }\end{array}$ \\
\hline (f) & CornK. 65v-66r: & $\begin{array}{l}\text { ala folnak vevlgyekre } \\
\text { down flow-3pl valley-pl-sublative } \\
\text { 'they flow down into the valleys' }\end{array}$ \\
\hline (g) & DomK. 16: & $\begin{array}{l}\text { Meg teere az fraterekhez } \\
\text { back turn-past-3sg the brother-pl-allative } \\
\text { 'he went back to the brethren' }\end{array}$ \\
\hline
\end{tabular}

Mátai $(1992,687)$ points out with respect to such examples that the preverb-verb complex occurs with a different kind of adverbial:

\begin{abstract}
"for instance, with verbs referring to position, non-changing or permanent state (in a neutral, non-emphatic sentence) the adverbial typically answers the question 'where': JókK. 66: ewlne a3 aztalnal : sederet in mensa ['would sit at the table'], whereas with directional preverbs, an adverbial answering the question 'where to' is required: BécsiK. 5: le vilo Ruth az azatoc oldalahoz — sedit ... ad messorum latus ['sat down to the harvesters' side'] [...] If, however, the sentence contains an emphatic constituent, the preverb-less verb can also have a 'where to' argument: [...] aztalhoz yleenek 'they sat [down] to the table'; the explanation being that the emphatic adverbial perfectivises the verb or makes it express a movement just like the preverb does..."
\end{abstract}

It is true that the preverb is capable of changing the argument structure of a verb in present-day Hungarian, too: yet in these examples something else is involved, in my view. The verb ül 'sit' has two argument structures to begin with: ül vhol 'sit at some place' and ül vhová 'sit to 
some place' (cf. ÉrtSz. 7: 102-3). The latter is exemplified by A kutya a küszöbre ült 'The dog sat down on the doorstep' or Fecskék ültek a telefondrótra 'Swallows sat down onto the telephone wire'. As can be seen, it is not emphasis that triggers the use of a directional argument since both sentences are neutral. That is, what the example from BécsiK. above shows is rather that it was an adverb of vague conceptual content (le 'down') that preceded the verb (why it got there will be discussed below) and its interpretation was given by a concrete adverbial phrase (az aratók oldalához 'to the harvesters' side'). Later on, that adverb of relatively empty semantics lost its independence altogether and joined the verb.

It is of course true that a former adverb now unambiguously functioning as a preverb may often require the occurrence of certain argument types in the sentence. In the case of leül 'sit down somewhere', the adverbial is not a compulsory argument but rather an optional adjunct (Pista le|ült (a pamlagra) 'Steve sat down (on the sofa)'); but in that of leül 'serve a sentence', having a transitive argument frame instead of the original intransitive one, the verb requires an obligatory object argument (Pista le|ült három évet 'Steve served a sentence of three years'). ${ }^{1}$ Preverbs of a more concrete meaning may in fact require that their adverbial arguments occur overtly (e.g., Pista bele|esik az árokba 'Steve falls into the ditch').

It appears then that such complements required by the preverb may originate from exactly the specifying role referred to. The reason why the appositive-like adverbial may be omitted from beside le ül is the phenomenon observed with a number of preverbs that - perhaps as a token of linguistic economy - they may absorb the meaning of the complement that used to be there in an appositive role, e.g., Le|ül (egy székre/a földre) 'He sits down (on a chair/on the ground)', Fel|teszi a kalapját (a fejére) 'He puts his hat on (his head)', Le|száll (a vonatról/a buszról) 'He gets off (the train/the bus)'.

1.1.2. The other type is actually the inverse of the first. Pais $(1959,184)$ claims that another factor that may have played a role in the emergence of preverbs were

\footnotetext{
${ }^{1}$ In the case of a preverb-less version of the latter, a locative complement or a temporal object is still required, cf. Pista Tökölön ül 'Steve is sitting [serving his sentence] in Tököl' vs. Pista három évet ül (rablásért) 'Steve is serving [a sentence of] three years (for robbery)'.
}

Acta Linguistica Hungarica 51, 2004 
"adverbs that followed, for purposes of emphasis, an adverbially used noun phrase in a coordinate relationship. This is the type we can think of: $A$ szobában benn $\mid$ találta $\mid$ Palit 'In the room inside $\mid$ found $\mid$ Paul $=$ He found Paul in the room'. Az ebek a juhokat $\mid$ az akolba be $\mid$ hajtották 'The dogs the sheep | into the fold in $\mid$ drove = The dogs drove the sheep into the fold'. Az árpát | a szárán rajt | hagyta 'The barley | on its stalk on | left $=$ He left the barley on its stalk'. A lóra rá| tette | a nyerget 'On the horse on $\mid$ put $\mid$ the saddle $=$ He put the saddle on the horse'. PeerK. 129: Maria foldre lee eseek that can be divided as Mária | a földre lé | esék 'Mary | onto the ground down $\mid$ fell = Mary fell down onto the ground'. - In sentences of the above type, the items benn, be, rajt, rá, le etc. used in parallel with the adverbially used noun phrases subsequently got closer to, or merged into, the meaning of the verb."

The explanation of such constructions, then, is seen by Pais in that an adverbially used noun phrase can be complemented by a reinforcing adverb:

\footnotetext{
"Assume the following to be a typical construction in old times: Az erdöböl ki jön 'He comes out of the forest'. What was $k i$ 'out' more closely related to, in other words, what did it form a construction with: the adverbial $a z$ erdőböl 'from the forest' or the verb jön 'comes'? I think, the semantic link must have originally obtained with az erdöböl, because this was the only way in which a relatively realistic concept could be attributed to it: an instance of $k i$ 'out' without such a link makes no sense. Az erdöböl $k i$ 'out of the forest' could be attached to the verb taken together as a construction referring to a relation. Later, due to motivations arising in certain psychological or objective situations, $k i$ could get separated from that construction and associated with the concept of change referred to by the verb" (Pais 1959, 184)
}

As we can see, in both types, there is an "appositive-like" relationship between the adverb of vague conceptual content and the concrete adverbial noun phrase. The difference between the two versions is that, in the first, an adverb of vague conceptual content is subsequently specified by a concrete adverbial, whereas in the second, the concrete adverbial comes first and is complemented by a semantically more general adverb that follows it. In the second case, then, we have to do with a seemingly superfluous, redundant item; but such general adverbs may appear to be partly superfluous even when they precede the adverbial noun phrase. Why are they used at all, then? The answer is not easy to give. The main role must have been played by the pragmatic needs alluded to above: a more exact specification of information, the enhancement of the direction of movement. In addition, factors having to do with the "dynamism" of sentence structure may also have played a role - factors like the ones 
pointed out by Deme $(1959,192)$ with respect to the preverb-like use of the adverb ott 'there'.

Given that the effect of semantic and pragmatic factors in the emergence of preverbs is relatively easy to see, whereas the last-mentioned aspect of an item "turning into a preverb" has not been involved in related discussions to a sufficient extent so far, I will concentrate on that aspect in what follows.

In his paper, Deme investigates non-emphatic sentences and tries to find out why speakers prefer sentences that include ott along with an adverbial noun phrase to corresponding sentences lacking ott (with certain verbs, and with a level stress pattern). His initial example is the following:

(2) (a) A ház előtt egy bérkocsi vesztegelt. the house in.front a hackney-cab be-stranded-past-3sg 'In front of the house, a hackney-cab was stranded.'

(b) A ház előtt vesztegelt egy bérkocsi. the house in.front be-stranded-past-3sg a hackney-cab 'A hackney-cab was stranded in front of the house.'

(c) A ház előtt ott vesztegelt egy bérkocsi. the house in.front there be-stranded-past-3sg a hackney-cab 'In front of the house, there was a hackney-cab stranded.'

Deme claims that whereas $(2 \mathrm{a}-\mathrm{b})$ are very difficult to pronounce without bérkocsi and a ház elött, respectively, carrying sentence stress (given that, with main stress on the verb, the rendering is rather artificial), in the version involving ott, that enterprise is successful. Deme then investigates the issue thoroughly on the basis of a corpus and comes to the conclusion that this solution is especially frequent with the verb van 'be', as well as with verbs referring to position (e.g., ül 'sit', áll 'stand', fekszik 'lie'), verbs referring to being somewhere (e.g., lakik 'dwell', táborozik 'camp', él 'live', telel 'spend the winter'), verbs referring to undirected movement (e.g., megy 'walk', lépdel 'tread', ugrál 'caper', táncol 'dance'), and intransitive verbs referring to a state-like process (e.g., ragyog 'shine', villog 'glitter', tátong 'gape'). It is also frequently found with verbs denying some form of movement - this time, not only with intransitive but also 
with transitive ones (e.g., marad 'stay', reked 'get stuck', pusztul 'perish', and hagy 'leave', felejt 'forget (somewhere)', tart 'keep', respectively). ${ }^{2}$

Deme goes on to claim the following $(1959,192)$ :

\begin{abstract}
"The item ott 'there' in most of the sentences listed is used in a preverb-like manner in order for the predicate to be able to stand in a straight word order and carry some degree of stress, without some other constituent receiving main stress that would otherwise unavoidably follow from the stresslessness of the verb. - But that preverb-like use of ott characterises the sentence rather than the verb: ott is not there for semantic reasons but for reasons having to do with the dynamism of sentence structure; hence, the complex ott + verb is not a lexical construction but a syntactic one both in terms of its origin and in its character."
\end{abstract}

This conclusion is quite acceptable in my view and is presented by Deme as supported by two main arguments. First, he points out that the occurrence of the adverb ott is not necessary in cases where there is some other way to make the verb carry stress. This can be done, for instance, with the help of the stressless modifier csak 'only' whose appearance renders that of the preverb-like ott superfluous in terms of "sentence dynamism":

(3) Péter csak állt szótlanul, s egy pillantást sem vetett

Peter only stand-past-3sg speechless and one glance-acc nor cast-past-3sg

Marira.

Mary-sublative

'Peter was just standing speechless, without even casting a glance at Mary.'

His second argument, and the one that is more important with respect to the emergence of preverbs in general, runs as follows: It is not unprecedented even for proper preverb-verb complexes "that their preverb only occurs when the verb is stressed, that is, the sentence is non-emphatic; otherwise, when the predicate is not stressed, they stand without the preverb rather than in the inverse order verb-preverb" (Deme 1959, 192). Consider some examples:

(4) (a) (i) Betegsége teljesen étvágytalanná tette, illness-3sg totally appetite-less-translative make-past-3sg de három nap után végre megpróbált enni. but three day after finally prev-try-past-3sg eat-inf

${ }^{2}$ In the last two groups, lexicalisation has already started. For instance, otthagy 'leave there, forget to take along' is spelt solid, suggesting that the item is lexicalised as a preverb+verb complex. 
(ii) Betegsége teljesen étvágytalanná tette, illness-3sg totally appetite-less-translative make-past-3sg de három nap után végre enni próbált. but three day after finally eat-inf try-past-3sg

'Due to his illness, he totally lost his appetite, but after three days he at last tried to eat something.'

(b) (i) Kirohant az utcára, s elkezdett ordítani. out-rush-past-3sg the street-subl and prev-begin-past-3sg shout-inf

(ii) Kirohant az utcára, $\mathrm{s}$ ordítani kezdett. out-rush-past-3sg the street-subl and shout-inf begin-past-3sg

'He rushed out to the street and started to shout.'

(c) (i) A parasztok végül megindultak a kastély felé. the peasant-pl finally prev-start-past-3sg the castle toward

(ii) A parasztok végül a kastély felé indultak. the peasant-pl finally the castle toward start-past-3sg

'The peasants finally made for the castle.'

I think that Deme's insight with respect to the occurrence of ott in certain sentences may bear upon the emergence of preverbs, too. It is known that in sentences of neutral interpretation and flat prosody (Deme's nonemphatic sentences), each major constituent carries a roughly equal degree of stress: none of the constituents is more prominent than the others. In non-neutral sentences, however, one of the constituents is assigned sentence stress (this can be either the verb or the constituent immediately preceding it): but this entails that the stress on that constituent "eradicates" stresses on anything that follows (sentences with eradicating prosody). These rules apply to most verbs, except for two groups of verbs: stress avoiding and stress requiring ones (cf. Komlósy 1992, 339).

Considering the semantic groups of stress avoiding verbs in Komlósy $(1992,341)$, we find that they more or less coincide with the verbs that in Deme's empirical study turned out to require the occurrence of ott in non-emphatic sentences (van 'be', marad 'stay', húzódik 'range', található 'be found'; hagy 'leave', felejt 'forget', tart 'keep', talál 'find', etc.). This coincidence is to be expected in view of the fact that stressing a stressavoiding verb results in an ungrammatical sentence:

(5) (a) *Az 'újságosbódé 'található a 'következő sarkon. the newsstand find-able the next corner-superessive

'The newsstand can be found at the next corner.'

(b) *Az 'újságosbódé "található a következő sarkon. the newsstand find-able the next corner-superessive 'The newsstand can be found at the next corner.' 
One possibility of avoiding stressing the verb is to make the adverbial noun phrase precede the verb:

(5) (c) Az 'újságosbódé a 'következő sarkon található. the newsstand the next corner-superessive find-able 'The newsstand can be found at the next corner.'

If, however, we do not wish to end the sentence with the verb but want to avoid its being stressed, we have to insert a local adverb to precede it whose stress will make it possible for the verb to lose its stress:

(5) (d) Az 'újságosbódé 'ott /'itt található a 'következő sarkon. the newsstand there/here find-able the next corner-superessive 'The newsstand can be found there/here, at the next corner.'

(e) A 'pénztárcámat 'ott /'lent felejtettem az 'újságosnál. ${ }^{3}$ the wallet-1sg-acc there/down forget-past-1sg the newsagent-adessive 'I left my wallet there/down there with the newsagent.'

What follows from all this? I think what follows is that the emergence of some of the preverbs may partly be due, along with the pragmatic and semantic considerations referred to above, to the prosodic factor that Deme observed with respect to the use of the adverb ott. In the case of stress avoiding verbs, stress on the verb results in an ungrammatical sentence, hence unless the verb is at the end of the sentence (or rather, in a position immediately following a stressed argument or adjunct), an adverbial item of the ott type is required in order to keep the grammaticality of the sentence. ${ }^{4}$ The group of stress avoiding verbs, however, constitutes a relatively small and atypical group, therefore - as an anonymous reviewer

${ }^{3}$ The inserted adverb can obviously not only be ott 'there': with a directional argument, oda 'there to, to that place' can be used, e.g., * A 'könyv 'került 'Péterhez, vs. A 'könyv "Péterhez került 'The book got to PETER', but: A 'könyv 'oda került 'Péterhez 'The book got to Peter'.

${ }^{4}$ On the other hand, neutral word order always results in verb stress in the case of stress requiring verbs (except if they are preceded by a manner adverbial in which case the latter will bear stress in most cases). All other constituents preceding an unstressed verb are to be interpreted as focus (cf. Komlósy 1992, 342): 'János '(nagyon) szeret 'olvasni 'John likes to read (very much)'; János "olvasni szeret 'It is to read that John likes'. Komlósy $(1992,341-3)$ claims that it is mostly verbs expressing emotional attitude or possibility/ability (e.g., szeret 'like', kedvel 'be fond of', utál 'detest', gyülöl 'hate'; gátol 'hamper', akadályoz 'hinder', szabad 'be allowed', lehet 'be possible') that belong here. From our point of view here, it is interesting that these verbs tend not to have versions with preverbs: apart from a couple of exceptions, all that can be added to them is the preverb meg-, and 
has also pointed out to me - it does not provide us with a broad enough basis of explanation to account for a historical process as widespread and resulting in such a large group of verbs as the emergence of preverbs. On the other hand, a preverbal adverb may be "useful" in the case of verbs of a less marked stress behaviour, too, in order for the sentence to be of a really neutral stress pattern. Consider the following examples:

(6) (a) 'Péter 'megy az 'utcán.

Peter go-3sg the street-superessive

'Peter is walking in the street.'

(b) 'Péter 'ott megy az 'utcán.

Peter there go-3sg the street-superessive

'Peter is walking there in the street.'

(7) (a) 'Péter 'jön az 'erdőből.

Peter come-3sg the forest-elative

'Peter is coming from the forest.'

(b) "Péter jön az erdőből.

Peter come-3sg the forest-elative

'It is Peter who is coming from the forest.'

(c) 'Péter az "erdőből jön.

Peter the forest-elative come-3sg

'It is from the forest that Peter is coming.'

(d) 'Péter ' $k i$ jön az 'erdőből.

Peter out come-3sg the forest-elative

'Peter is coming out of the forest.'

(e) 'Péter az 'erdőböl ' $k i$ 'jön.

Peter the forest-elative out come-3sg

'Peter is coming out of the forest.'

(8) (a) 'Péter 'megy az 'erdőbe.

Peter go-3sg the forest-illative

'Peter is going to the forest.'

(b) "Péter megy az erdőbe.

Peter go-3sg the forest-illative

'It is Peter who is going to the forest.'

(c) 'Péter az "erdőbe megy.

Peter the forest-illative go-3sg

'It is to the forest that Peter is going.'

(d) 'Péter 'be megy az 'erdőbe.

Peter in go-3sg the forest-illative

'Peter is going into the forest.'

probably even that can only be attached to them since the time its perfectivising function has developed, and only in an analogical manner. 
(e) 'Péter az 'erdőbe 'be'megy.

Peter the forest-illative in go-3sg

'Peter is going into the forest.'

Sentences (6a) and (6b) are not really different, even though the use of ott makes it more unambiguous that the sentence is of flat prosody. In (6a), it takes special care not to emphasise the subject since even the slightest extra emphasis will indicate that it is in focus position: "Péter 'megy az 'utcán. ₹ "Péter megy az utcán 'It is Peter who is going in the street'. This sentence expresses a locative relation; most preverbs, however, go back to lative (directional) adverbs. But if we consider (7a) and (8a), expressing an elative and an illative relation, respectively, we see that they are also somewhat difficult to pronounce with a neutral stress pattern. The focussed versions $(7 \mathrm{~b}-\mathrm{c})$ and $(8 \mathrm{~b}-\mathrm{c})$ are a lot more acceptable. Therefore, if we want a neutrally stressed sentence, we can make use of the solution seen before: the insertion of a conceptually empty adverb before the verb. It is true that sentences $(7 \mathrm{~d}-\mathrm{e})$ and $(8 \mathrm{~d}-$ e) are somewhat unusual to our present-day native intuition with the adverb pronounced separately (thus: 'Péter "be megy az "erdőbe 'Peter goes in, to the forest', as opposed to 'Péter 'bemegy az 'erdőbe 'Péter goes into the forest'), it is nevertheless more than conceivable that the data from early documents (of which there are quite a few) showing spellings with the adverb and the verb in two words are reflexes of that earlier situation. These items are of course not real arguments of the verbs that follow them; they could be more appropriately characterised as free adjuncts. Given, however, that a verbal modifier and an immediately following verb count as one word for stress purposes (i.e., the stress is deleted after a verbal modifier, cf. É. Kiss 1998, 37), the adverb gradually fuses with the verb as time goes by, and becomes the anterior constituent of a compound, or a preverb proper.

The occurrence of "appositive-like" adverbs that can be taken to be predecessors of preverbs, then, must have been primarily due to communicative and pragmatic reasons (e.g., a strive for accuracy and expressivity) but an additional factor that may have facilitated their emergence is the prosodic role that Deme observed in connection with the preverblike use of ott 'there'. The adverbial constituents of general conceptual content occurring in the above examples make it possible for the verb 
to lose its stress and for sentences with an unambiguously neutral stress pattern to be produced. ${ }^{5}$

\title{
1.2. Preverbs from postpositions
}

The two types we have looked at so far are likely to have provided us with the earliest way of the emergence of preverbs. It appears that it is the oldest and most frequently used Hungarian preverbs that came into being in that way, the meanings of which may of course have subsequently changed considerably, as in their uses to express perfectivity or verbal aspect. There are, however, other preverbs, too, whose way of emergence differs from what we saw above. Some preverbs also occur as postpositions; the reason being that in certain postpositional phrases the postposition may change sides and go over to the verb. Pais $(1959,184)$ discusses that type, too: "It appears furthermore that in a large number of cases the adverb did not enter into relation with the verb on its own but rather as a postposition attached to a noun."

It is well known that postpositions expressing a pure relational meaning used to be independent nouns and their forms involving a (primary) case marker

\begin{abstract}
"followed a noun in a possessive construction, and the phrase thus formed served as an adverbial complement of the predicate. Thus: ék(et) $\mid f a+$ bel-é | üt 'wedge(-acc) | tree + inside-poss $\mid$ hit $=$ drive a wedge into (to the interior of) a tree'; hegy + al-á $\mid$ megy 'hill + underside-poss $\mid$ go $=$ go under (to the foot of) a hill'; lovát $\mid$ ház + mig-é $\mid$ vezeti 'horse-possacc $\mid$ house + back-poss $\mid$ drive $=$ drive one's horse behind (to the back of) the house'. [...] Second constituents of such case-marked possessive constructions, that is, postpositions, mainly turned into inflexions. [...] Other directions of development, however, were also taken. In particular, a postposition - whether or not it turned into an inflexional suffix in the meantime - may have drifted apart from the preceding noun rather than getting even closer to it such that it swung over to the verb. Thus, some postpositions turned into both a case marker and a preverb, while others just turned into a preverb." (Pais 1959, 184)
\end{abstract}

Kiefer-Ladányi $(2000,482)$ list the following preverbs as going back to postpositions: alá 'to underneath', elé 'to before', fölé 'to above', mellé

${ }^{5}$ Perhaps this is why stress requiring verbs include those combined with meg- only: if a verb is stress requiring to begin with, i.e., it "wants to" bear main stress itself, no proto-preverb going back to a real adverb may stand before it to take stress away from it.

Acta Linguistica Hungarica 51, 2004 
'to beside', mögé 'to behind', utána 'to after', as well as át 'through', keresztül 'across', túl 'over'. They do not motivate the division they make within this group of items - perhaps it is meant in terms of their diverse syntactic behaviour (the second group contains postpositions that cooccur with case-marked nouns). In my view, however, that distinction between the two groups of postpositions is paralleled by a distinction between the groups in their behaviour as preverbs, and can be traced back to the two different ways in which they came into being.

1.2.1. The six items listed as the first group belong to a large group of postpositions that form a possessive construction with their head noun and are simultaneously connected to the predicate of the sentence (Sebestyén 1965, 190 refers to them as "double bondage" postpositions). Most of such items turned into postpositions by grammaticalisation, and some of them lost some more of their independence and ended up as case markers. The latter are not involved in the process described here. The six items listed above, however, did not always get coupled with their head nouns but "defected" to the verbs dominating them. That defection had some morphosyntactic consequences: as opposed to the uninflected noun plus postposition complexes that the preverb-less verbs govern, the preverb-verb combinations govern an obligatory dative argument:

(9) (a) (i) Péter az ágy alá bújik.

Peter the bed under hide-3sg

(ii) Péter alá|bújik az ágynak

Peter under|hide-3sg the bed-dative

'Peter hides under the bed.'

(b) (i) Károly a kép mögé néz. Charles the picture behind look-3sg

(ii) Károly mögé|néz a képnek. Charles behind|look-3sg the picture-dative

'Charles looks behind the picture.'

That difference is less surprising if we think of the fact that in constructions like az ágy ala 'under the bed', a kép mögé 'behind the picture' the postposition originally had a possessive relationship to the noun before it. This can sometimes be explicitly marked, as in the classic line from Arany's Toldi: Jól tudom, mi lappang bokrodnak megette 'I know what is hidden behind your bush [behind of your bush]'. Another well-known linguistic fact is that the dative and the genitive are historically related. That made it possible for the marker of the possessive to develop from 
the dative inflection; but there are further pieces of evidence for that relationship, too. Think of Hungarian "dative possessive" constructions (A királynak volt egy csodaszép leánya "The king had a beautiful daughter') or constructions in other languages where possession is expressed by the dative (e.g., French ce livre est à moi 'that book is mine [to me]'; Russian еми пять лет 'he is five years old [to him five years]'). We may also mention Hungarian constructions in which a dative noun is followed by another noun inflected with a 3sg possessive marker that could be the possessed entity belonging to the former, cf. e.g., JókK. 161-2: a3 naualÿas anÿanak meg adak holt gyermeket : miserae matri mortuum filium reddiderunt 'The miserable mother was given back her dead son'.

Taking all that into consideration, the change of argument structure referred to above is not unexpected. Whereas the preverbs discussed in section 1.1 used to be independent adverbs that were made more precise by the concrete adverbial noun phrase of the sentence (ki megy a házból 'out go the house-elative = go out of the house'), in the present type there is just one adverbial complement. But that single adverbial is expressed by a postpositional phrase in which the (proto-)postposition is not an independent item. If that item "defects" to the verb, the nominal part of the postpositional phrase remains on its own. That fact - assuming unmarked possessive constructions - might result in a disturbing instance of homonymy since there would be nothing to indicate which constituent is the subject, and which is the adverbial, cf. (10b):

(10) (a) A kutya alá bújik a macska.

the dog under hide-3sg the cat

'The cat hides under the dog.'

(b) *A kutya alá|bújik a macska. the dog under|hide-3sg the cat

'The dog hides under the cat /The cat hides under the dog.'

However, that case does not occur since the verb in its preverb-adorned version retains its directionality and since the postposition originally containing the direction marking has now become an anterior constituent of the verb (being its predicate) the adverbial relation is marked on the nominal part of the postpositional phrase. The fact that it is the dative marker that is used for that purpose is not that surprising for two reasons: first, the $-n a k /-n e k$ of the dative itself evolved from the directional inflection -nak/-nek 'to', and second, the dative is closely related to the genitive. 
1.2.2. The other three preverbs listed above (át, keresztül, túl), on the other hand, exhibit a different behaviour: these do not require a dative suffix but retain the suffix that they also govern as postpositions:
(11) (a) (i) Az asztalon át nyúl a könyvért. the table-superessive across reach-3sg the book-causalis
(ii) Át|nyúl az asztalon a könyvért. across|reach-3sg the table-superessive the book-causalis
'He reaches across the table for the book.'

(b) (i) A folyó a városon keresztül folyik. the river the town-superessive through flow-3sg

(ii) A folyó keresztül|folyik a városon. the river through|flow-3sg the town-superessive

'The river flows through the town.'

(c) (i) A jegenyefa a tetőn túl nyúlik. the poplar the roof-superessive beyond reach-3sg

(ii) A jegenyefa túl|nyúlik a tetőn. the poplar beyond|reach-3sg the roof-superessive

'The poplar reaches beyond the roof. ${ }^{, 6}$

The reason for that difference, in my view, is that these postpositions do not go back to possessive constructions but to adverbial constructions of an appositive character. That is also the explanation of their requiring a case ending on the noun they cooccur with: they specify, make precise, or explain the meaning of the case-marked noun preceding them (cf. Sebestyén 1965, 198). In fact, then, we have double adverbials again, just like in the cases in section 1.1. The difference primarily lies in the fact that in those cases the appositive-like relationship obtained between

\footnotetext{
${ }^{6}$ Along with semantic development, changes in argument structure may obviously occur. For instance, keresztül 'across' can be used in a concrete meaning, as a postposition, with the verb lép 'step': A küszöbön keresztül lép a szobába 'He steps into the room across the threshold'. However, when used as a preverb, the occurrence of keresztül excludes that of the other concrete complement ( $a$ szobába): Keresztüllép a küszöbön 'He steps across the threshold [superess.]'. This is probably related to the fact that the adverbial argument of the preverb-verb complex can alternate with an accusative argument: Keresztüllépi a küszöböt 'He steps over the threshold [acc.]' And if the remaining complement is of an abstract meaning, the other adverbial would be absolutely out of place: Keresztüllép a problémán 'He gets over the problem [superess.]'. In addition, substitution by an accusative argument is all but impossible (or at least highly unusual) in this case: ?Keresztüllépi a problémát 'He gets over the problem [acc.]'.
} 
elements that were capable of being located in non-adjacent positions of the sentence, whereas here the adverb stands right after the suffixed noun. In these constructions, then, it was easy for the (proto-)postposition to defect to the verb, given that it was rather loosely connected to the noun in the first place. But since the remaining noun was inflected itself, the change of argument structure observed in the previous section was not needed, either: the preverb-verb complex could simply retain the original case frame of the postposition.

\subsection{Preverbs from idiom chunks}

There is yet another way for preverbs to emerge, although one that is more recent and less frequent than the previous ones: emergence from parts of idioms. Of the present stock of Hungarian preverbs, agyon- 'over, to death' and tönkre- 'over, to ruins' definitely belong here; some pieces of the literature (including ÉrtSz.) classify a number of other similar elements as preverbs, too (e.g., cserben 'in the lurch', észre 'to one's senses', kölcsön 'as a loan', létre 'to existence', sikra 'to the field', újjá 're-, into a good shape', végbe 'into effect', véghez 'to the end'). These latter elements are not productive at all, hence most of the relevant literature does not classify them as preverbs; but agyon- and tönkre- are relatively productive, therefore they are usually taken to be preverbs. ${ }^{7}$

Agyon- and tönkre- are among the most recent preverbs of Hungarian. Klemm $(1928,258)$ points out that agyon was a plain adverbial in the 16th century, and agyon|üt 'strike dead' simply meant 'knock on the head', e.g., 1575: bottal ẃteotte volt agion', kübe meg sẃketwlt 'he knocked him on the head with a stick, that made him deaf'. ${ }^{8}$ Thus, agyon first only occurred with üt 'hit', ver 'beat', developing into a set phrase after some time. Given that hitting someone on the head often led to death, it was as early as in the second half of the 16th century that the perfectivising meaning '〈hit, strike, beat〉 heavily' $\rightarrow$ 'to death' began to arise. But at the same time, its original meaning started to be overshadowed. It is in the late 17th century that agyon began to spread to other verbs in this new sense, e.g., agyon lötte 'shot him dead'

${ }^{7}$ The reason, I think, is that the semantics of these makes them eminently capable of fulfilling one of the most important tasks of preverbs: to express perfectivity.

8 The original meaning of agy was 'skull' or 'head'; its present meaning 'brain' is a later development (cf. TESz. 1, 106). 
(1691), agyonrúg 'kick dead' (1770), agyon tsiklándom 'I will tickle her to death', agyonitta magát 'he drank himself dead' (1792). The perfectivising 'to death' meaning evolved in the 19th century into a more peculiar shade of perfectivity, emphasising the frequency, too many repetitions, higher degree than desirable of the given action, e.g., agyonbeszél 'talk too much about', agyonsir 'cry too much over', agyondicsér 'praise to the skies', agyoncsókol 'smother with kisses', agyonhajszol 'overwork', agyonfázik 'be chilled to the bone', agyonhallgat 'kill by silence', agyontáncolja magát 'dance oneself to extreme fatigue', agyonissza magát 'drink oneself to death/drink heavily', agyonázik 'get drenched through'. ${ }^{9}$

Tönkre- is an even more recent development. It is questionable if it is in fact a preverb at all. Kiefer and Ladányi $(2000,482)$ classify it as a preverb on the basis of its productive patterns of combination, whereas Jakab (1976, 99; 1982, 66) does not. TESz. (III, 967) does not call it a preverb but speaks of tönkre-initial compounds that

\begin{abstract}
"were created with a syntactic contraction of the noun tönk 'stump' in the sublative with verbs expressing action, movement, or directedness. The adverb tönkre getting consolidated as a compound constituent and the metaphorical uses that the individual compounds assumed can be explained in various ways. It is possible that the development started in the vocabulary of shipping. It may have been based on the fact that ships sometimes got stranded on a tree stump in the water and the damage thus made in them caused them to sink, to be destroyed. The problem with this explanation is that the earliest occurrences in connection with shipping that we have data about are relatively recent; cf. 1897: ha tönkre viszi a hajót, lecsapják a tisztségéböl 'if he sails the ship over a stump, he will be dismissed from his position' (István Tömörkény) [...] It is also possible, however, that tönk in tönkre- originally referred to the wood-cutting block on which, in villages, discarded pieces of furniture were also split up." 10
\end{abstract}

Let us for the moment set aside the question of whether tönkre- is a preverb or rather the anterior constituent of a few lexicalised compound verbs. Let us concentrate on the issue why, in the case of a number of such anterior members (like cserben, észre, etc., see above), it is suggested by some that they should be seen as belonging to the stock of Hungarian preverbs. The source of uncertainty may be that these items of the vocabulary were idiomatic units (phrasemes) to begin with, but due to

${ }^{9}$ In popular usage, sometimes: agyonra [sublative], e.g., agyonra sózták a húst 'the meat was terribly oversalted'.

${ }^{10}$ Another possibility that cannot be excluded is that e.g., a cart could also get damaged by running over a stump. 
their frequent cooccurrence they fused to such an extent that their unitary character is now indicated in spelling, too (e.g., cserben|hagy 'leave in the lurch', tönkre|megy 'be ruined/destroyed', helyben|hagy 'approve of/beat up', etc.). This is not much of a problem in itself since we could simply say that these are not set phrases any more but lexicalised complex verbs that - similarly to other compounds that arose in sentences rather than analogically - came into being by losing the (potential) pause between their component parts due to having occurred together quite a lot. ${ }^{11}$ However, anterior compound constituents going back to idiom chunks behave syntactically in much the same way as preverbs do: for instance, in focussed sentences or in negation they get split from their verbal element, thus they retain their independence to some extent:

(12) (a) Péter JÁNost hagyta cserben, nem Károlyt. Peter John-acc leave-past-3sg lurch-inessive not Charles-acc 'It was John who Peter left in the lurch, not Charles.'

(b) Nem Péter ment tönkre, hanem János. not Peter go-past-3sg stump-sublative but John 'It was not Peter who went bankrupt but John.'

A number of items still functioning as idiom chunks behave in the same way:

(13) Férjhez Kati ment, nem Eszter. husband-allative Kate go-past-3sg not Esther 'It was Kate who got married, not Esther.'

The fact that there is hardly any difference in syntactic behaviour between (i) compound-constituent-like forms that are still idiom chunks like férjhez (ad) 'marry off' (férj 'husband', ad 'give'), sorba (áll) 'queue up' (sor 'queue', áll 'stand'), lépre (megy/csal) 'be taken in/take in' (lép 'bird-lime', megy 'go', csal 'lure'), (ii) preverb-like former idiom chunks

${ }^{11}$ In the phraseological literature, Somhegyi (1988; 1992) suggested that the terms 'monophraseme' and 'pseudo-monophraseme' should be introduced. Examples of the former, in his view, would be items like felszarvaz 'make a cuckold of' ( szarvakat rak vki fejére 'id., lit.: put horns on someone's head') or kikosaraz 'reject (a suitor)' ( $\leftarrow$ kosarat ad vkinek 'id., lit.: give someone a basket'). Items like cserbenhagy, tönkremegy would be assigned to the class of pseudo-monophrasemes since they are actually made up of two elements, it is just the spelling that suggests their unity, just like in the case of baklövés 'blunder, lit.: shooting a buck', köpönyegforgató 'turncoat', szörszálhasogatás 'hair-splitting' (whereas bakot lo" 'commit a blunder', köpönyeget fordit/forgat 'turn one's coat', szörszálat hasogat 'split hairs' are straightforward phrasemes/set phrases).

Acta Linguistica Hungarica 51, 2004 
like cserben- 'in the lurch', helyben- 'in place', véghez- 'to the end', and (iii) preverbs proper like be- 'in', $k i$ - 'out', meg- [perfectiviser] can be explained by a property that their functions share: all of them occur in sentences as verbal modifiers. What is common in their syntactic behaviour is that they occupy a position within the VP that is different from that of complements: whereas the latter follow the verb, verbal modifiers precede it in the neutral pattern. As has been mentioned, the modifier and the verb that follows it count as a single word in terms of stressing, a factor that favours their fusion.

The question is what motivates the claim that certain preverbal elements are preverbs, whereas others are just anterior constituents of lexicalised compound verbs. Spelling can of course not be a reliable point of departure given that, as the examples so far suggest, it is mainly a matter of taste and intuition on the part of dictionary makers whether a modifier that is part of an idiom retains its relative independence or is degraded into the anterior constituent of a compound. Whether or not an item is a preverb depends on the way that word class is defined and on the results of certain syntactic tests. In that connection, the semantic non-transparency of the relationship between the components is often referred to; but an even more important criterion is that of productivity, or the number of verbs that can be formed with the given item (cf. Soltész 1959, 15-6; Kiefer-Ladányi 2000, 480-2). These two do not of course correlate in all cases. For instance, haza- 'home' combines with a large number of verbs but, since these combinations usually do not mean anything else but the mere sum of their parts, Soltész $(1959,15)$ does not regard this item as a preverb. On the other hand, although cserbenhas an idiomatic meaning in cserbenhagy 'leave in the lurch', in terms of productivity it still remains an idiom chunk, or rather the anterior constituent of a lexicalised compound verb, since it only occurs in this single combination. ${ }^{12}$ The items agyon- and tönkre-, likewise going back to idiom chunks, however, are clearly classified as preverbs by KieferLadányi $(2000,501-13)$ on the grounds that they are highly productive. ${ }^{13}$

12 The expression cserben marad 'be left in the lurch' used to occur as an idiom (see Szarvas-Simonyi 1890, 412 [NySz]) but it did not evolve into a compound verb.

${ }^{13}$ It is worth briefly mentioning here that a somewhat similar process has occurred in German in expressions of the type vonstatten gehen, zuwege bringen, zugrunde gehen, etc. Up to the 19th century, these constructions were taken to involve prepositional phrases and spelt as zu Grunde gehen, zu Wege bringen, von Statten gehen, etc., as it is still done today in many other cases like zu Hause bleiben, 
Let us see in somewhat more detail the degree to which productivity is a reliable criterion of being a preverb.

\section{The size of the stock of preverbs in terms of productive rules of formation}

As we saw above, most grammars list agyon- as one of the preverbs of Hungarian. Yet, the Hungarian Dictionary of Definitions (ÉrtSz. I, 52-5) contains only 22 verbs with agyon- as a preverb. These are the following:

(14) agyonbeszél 'talk too much about', agyoncsap 'strike dead', agyoncsépelt 'hackneyed', agyoncsigáz 'overexcite', agyondicsér 'praise to the skies', agyondolgoztat 'overwork', agyondolgozza magát 'overwork oneself', agyongázol 'run sy over', agyonhajszol 'overfatigue', agyonhallgat 'kill by silence', agyonkínoz 'torment to death', agyonlő 'shoot dead', agyonnyom 'crush to death', agyonrúg 'kick to death', agyonsújt 'strike dead', agyonszorít 'crush to death', agyonszúr 'stab to death', agyontapos 'trample to death', agyonüt 'strike dead', agyonvág 'strike dead', agyonver 'beat to death', agyonzúz 'smash to death'

Although twenty-too verbs in the dictionary cannot be said to constitute a small group, we can be suspicious of the actual productivity of agyon-. Therefore, I have surveyed the loadedness of agyon- by the help of a present-day corpus having an electronic search facility. Having gone through the material of a CD containing all issues of the newspaper $M a$ -

\footnotetext{
in Betracht ziehen, außer Landes gehen, etc. Later, however, the constituents of some former prepositional phrases got adverbialised and joined their head verbs in terms of stress. As Fleischer $(1997,93)$ points out, the process of merger of such prepositional phrases was facilitated by their semantic development (gradually more abstract uses, the loss of certain semantic components of the noun) and their increasingly frequent occurrence. (An additional factor was that most of such expressions involved the preposition $z u$ : this brought some type-forming regularity into the change.) However, during the 1998 spelling reform, these phrases were meant to be revitalised in the sense that the adverb-like forms can be spelt separately, along with the earlier form. Thus, whereas earlier one had to write instand halten/setzen/bringen, zugrunde gehen, zuleide tun, zumute sein/werden, zunutze machen, zustande bringen/kommen, zutage bringen/fördern/kommen, etc., today the following forms are also seen as correct: in Stand halten, zu Grunde gehen, zu Leid(e) tun, zu Mute sein, zu Nutze machen, etc. On the other hand, the latter option is not open for cases like abhanden kommen, vonstatten gehen, $z u-$ nichte machen, zupass kommen, zustatten kommen, zuteil werden. Such changes in the rules of spelling, in my view, are only good for increasing the embarrassment of language users; they are quite unable to stop the historical process of grammaticalisation.
}

Acta Linguistica Hungarica 51, 2004 
gyar Hirlap published between 1994 and 2001, I found that the preverb agyon- is in fact rather productive: the search yielded a total of 1948 occurrences representing 208 different verb forms (including participles; in some of these cases, the corresponding finite verb would not be possible or would be highly unusual with agyon-). These verbs (and participles) are the following (the glosses in (15) are given with the preverbal agyonignored):

(15) agyon|adóztat 'tax', -affektál 'simper', -ajnároz 'fondle', -asszimilál 'assimilate', -átkozott 'cursed', -ázik 'get drenched', -babusgat 'pamper', -bagóz(ott) 'smoke(d)', -beszél 'talk', -bírál 'criticise', -bombáz 'bomb', -bonyolít 'complicate', -bürokratizál 'bureaucratise', -cenzúráz 'censor', -cicomáz 'adorn', -cigarettáz(ott) 'smoke(d)', -cikizett 'codded', -cirkalmaz 'do in a roundabout way', -citált 'cited', -civilizált 'civilised', -cizellált 'chiselled', -csap 'strike', -csépel 'thresh', -csepült 'abused', -csigázott 'stimulated', -csikarva 'twisting', -csiszolt 'polished', -csócsált 'champed', -csomagol 'pack', -dédelget 'caress', -dekorál 'decorate', -dicsér 'praise', -dicsőít 'glorify', -díszít 'decorate', -dizájnolt 'designed', -dobál 'throw about', -dolgoztat 'make work', -doppingol 'dope', -dorongol 'cudgel', -dresszúráz 'drill', -éget 'burn', -ékszerezett 'jewelled', -elektronizált 'electronised', -elemez 'analyse', -ellenőriz 'control', -emészt 'digest', -erősít 'strengthen', -értelmez 'interpret', -eszi (magát) 'eat (oneself)', -etet 'feed', -fagy 'freeze', -fárad 'get tired', -fáraszt 'tire', -favorizál 'favour', -fegyelmez 'discipline', -félt 'be anxious about', -fetisizál 'make a fetish of', -firkál 'scribble', -foglalkoztat 'employ', -foltoz 'patch', -fotóz 'photograph', -föz 'cook', -frusztrált 'frustrated', -füszerez 'spice', -gépesített 'mechanised', -gyilkol 'murder', -gyötör 'torture', -hajszol 'pursue', -hajt 'drive', -hallgat 'be silent', -halmoz 'heap', -hangsúlyoz 'emphasise', -hangszerel 'score', -használ 'use', -hierarchizált 'hierarchised', -hirdetett 'advertised', -hordott 'worn', -hozsannázott 'praised', -hüt 'refrigerate', -húz 'pull', -ideologizált 'ideologised', -idéz 'quote', -igekötőzött 'preverbed', -ingerelt 'irritated', -interjúvol 'interview', -írt 'written', -ismert 'known', -ismételt 'repeated', -istápol 'support', -ivott 'drunk', -ízesít(ett) 'flavour(ed)', -izzadt 'sweated', -játszik 'play', -karcol 'scratch', -kárhoztatott 'blamed', -karikírozott 'caricatured', -kínoz 'torment', -kommunikál 'communicate', -komplikál 'complicate', -konstruál 'construct', -kopíroz 'copy', -kopott 'worn', -koptat 'wear out', -kozmetikált 'pipe-clayed', -kritizált 'criticised', -lapít 'flatten', -látványosított 'spectacularised', -lelkiz 'schmooze', -lő 'shoot', -lyuggat 'perforate', -machinál 'machinate', -magasztal 'praise', -magyaráz 'explain', -manipulál 'manipulate', -másol(t) 'copi(ed)', -mázol(t) 'paint(ed)', -mediatizált 'mediatised', -menedzselt 'managed', -mérgezett 'poisoned', -misztifikált 'mysticised', -montírozott 'mounted', -mosott 'washed', -motorizált 'motorised', -mozog 'move', -mütrágyáz 'fertilised', -nevet 'laugh', -nyaggat 'vex', -nyom 'crash', -nyugtatóz 'sedate', -nyúz 'exploit', -olvas 'read', -pallérozott 'civilised', -passzíroz 'sieve', -permetez 'spray', -plasztikázott 'face-lifted', -platformosított 'platformed', -politizál(t) 'politicise(d)', -pszichologizált 'psychologised', -púderez(ett) 'powder(ed)', -püföl 'thrash', -rágalmaz 'slander', -ragasztott 'pasted', -rágott 'chewed', -reformál(t) 'reformed', -reklámoz(ott) 'advertise(d)', -restaurált 'restored', -rongyolt 'ragged', -rugdal 'keep kicking', -rugdos 'keep kicking', -rúg 'kick', -sanyargat 'scourge', -sarcol 'hold to ransom', -sikált 'scrubbed', -simogat 


\begin{abstract}
'stroke', -skandált 'scanned', -smukkozott 'jewelled', -sóz 'salt', -stilizált 'stylised', -strapált 'worn down', -sújt 'strike', -süt 'bake', -szabályoz 'regulate', -szabdal 'slash', -szankcionál 'sanction', -szárad(t) 'dry (dried)', -szennyez(ett) 'pollute(d)', -szerepeltet(ett) 'cause(d) to figure', -szeret 'love', -szeretget 'caress', -szervez(ett) 'organise(d)', -szoláriumozott 'tanned', -szponzorál(t) 'sponsor(ed)', -sztárol(t) 'promote(d)', -szubvencionál(t) 'subsidise(d)', -szúr 'stab', -szurkál 'prickle', -takargat(ott) 'conceal(ed)', -taktikáz 'manoeuvre', -támogat(ott) 'support(ed)', -táplál(t) 'feed (fed)', -technicizált 'technicised', -terhel 'load', -tetovál(t) 'tattoo(ed)', -tipor 'trample', -titkol(t) 'hide (hidden)', -töm 'stuff', -töpreng 'brood', -trükköz 'trick', -turbózott 'turboed', -tüzdel(t) 'interlard(ed)', -un 'be bored of', -utál(t) 'detest(ed)', -ünnepel 'celebrate', -üt 'strike', -vág 'strike', -vallat 'interrogate', -véd(ett) 'defend(ed)', -vegyszerezett 'chemicalised', -ver 'beat', -versenyeztet 'make compete', -világított 'lit', -vitat 'discuss', -zenél 'make music', -zselézett 'greased', -zsúfol 'cram'
\end{abstract}

The examples show the productivity of the pattern (with the shared meaning component 'very much, too much'): the preverb can be applied to some quite recent or even nonce-derived verbs/participles like agyonmediatizál 'over-mediatise', agyonszoláriumozott 'extremely tanned', agyontechnicizált 'over-technicalised', agyonsmukkozott 'laden with jewels', etc. On the other hand, it can be seen that the preverb is far from applicable to finite verb forms in all the cases: it is at least as frequently used with past participles. It would of course be possible to back-form a verbal version from these but in many cases it would sound strained. For instance, agyonigekötözött 'stuffed with preverbs' sounds fine as a participial modifier but would perhaps be less acceptable if used as a verb:

(16) Káromkodásai mívesen cizelláltak, szórövidítései komoly filozófiai távlatokat összegeznek, a politikai beszédekből bőségesen merített horrorisztikus képzavarai és dagályos félrebeszélései, a túlragozott, agyonigekötőzött, toldaléktól burjánzó szavak és a féktelenre rontott mondatszerkezetek a kor teljes, enciklopédikus összefoglalását adják ki.

(Magyar Hírlap, 5 October 2000, 13)

'His swear-expressions are finely chiselled, his clippings span sincere philosophical perspectives, his horrid mixed metaphors and bombastic ravings taken profusely from political speeches, his over-inflected words stuffed with preverbs and rampant with suffixes, and his wildly corrupted sentence structures make out a full encyclopaedic epitome of the period.'

Given that the same search program has access to a text corpus of the issues of Vasárnapi Újság from 1854-1860, for curiosity's sake I examined the loadedness of agyon in that corpus, too. The results superbly illustrate the process of linguistic change: the number of occurrences found is only 194 (roughly $10 \%$ of the occurrences in Magyar Hirlap that reflect the late-20th-century situation). Those 194 tokens are distributed over 
23 different verbs, a number seemingly corresponding to the number of entries in ÉrtSz.; however, on closer scrutiny it turns out that the two sets of verbs are not the same. Of the 22 verbs in the dictionary, 12 occur in Vasárnapi Újság, too, and the other 11 of the corpus are not included in the dictionary. The overlap obviously concerns the possibly most frequent agyon-forms (e.g., agyoncsap 'strike dead', agyonlo" 'shoot dead', agyonüt 'strike dead', agyonver 'beat to death'), and it is likely that the verbs included in the dictionary but missing from the corpus (e.g., agyondicsér 'praise to the skies', agyonhajszol 'overwork', agyonrúg 'kick to death') were also in existence already in the mid-nineteenth century. On the other hand, the older corpus also contains neologisms that show a productive pattern of the secondary meaning of the preverb: agyonczinczog 'scrape the violin endlessly'.

(17) A zenejárvány, különösen a zongoratyphus s az énekkolera, mellynek áldozatai sajátkép azok, kik megkiméltettek általa, jellemző oldala Bécsnek s nem ritkán találni vargamühelyt, hol a mustával az atya „Herr von” Breselmayer például üti a taktust leányasszonyának rabvallató trilláihoz s őrjitő futamaihoz, ide nem számitva a dél felől a zenedéből hazakerült Szepi urfit, ki észlázitó hegedűdühöngéseivel agyonczinczogja az embert.

(Letters to the Editor, Vasárnapi Újság, 18 December 1859, 18)

'The musical epidemic, especially the piano typhus and the singing cholera, whose victims are strangely those who are immune to it, is a characteristic trait of Vienna and you often find shoemaker's shops in which the father, say Herr von Breselmayer, beats the time with his last to his daughter's cross-examining warbles and maddening roulades, not to mention master Seppl coming home from the music school around noon who scrapes you to death with his breath-taking frenzies on the violin.'

It is conspicuous, on the other hand, that - although in 153 of the 194 occurrences agyon is in immediately preverbal position - it is spelt as a separate word in 51 cases. Some of these latter are of the type agyon üt 'strike', agyon lo" 'shoot', agyon ver 'beat' but it is unlikely that agyon in these should be interpreted as 'on the head, on the skull'. The more so since the same verbs also occur in the way they are used today, i.e., spelt solid. In addition, agyon is found written separately in a number of cases where it is to be taken metaphorically and clearly requires the interpretation 'very much, too much', as in agyon kaczagja magát 'laugh oneself to death', agyon éhezi magát 'starve oneself to death', agyon táncolja magát 'dance oneself to death', agyon unja magát 'kill oneself by boredom'. The last one of these occurs spelt solid, too: agyonuntam 
már magam a nagyvárosban 'I was bored to death in the city' (Vasárnapi Újság, 24 July 1859).

All this shows grammaticalisation in progress: functionally, the idiom chunk is a verbal modifier just like a normal preverb is but its degree of independence is higher. The state of the language as shown by Vasárnapi Ujság reflects the fact that agyon has done roughly two-thirds of the way towards becoming a preverb. ${ }^{14}$

Let us now examine the productivity of the anterior constituent tönkre 'to ruins'. In ÉrtSz. (6, 773-4), we find a mere six of such forms:

${ }^{14}$ It is interesting to note that Hungarian also has an adverb halálra 'mortally, to death' that is used partly in the same sense as agyon is and that occurs fairly often, too: halálra gázol 'run over', gyötör 'torment', kinoz 'torture', sebez 'wound', sújt 'strike' (all: 'and kill'), etc. Some people take it to be a loan translation of German zu Tode. But Grétsy-Kovalovszky (1980-1985, I 124) [NyKk.]) is of the opinion that that view is incorrect since such expressions may have developed within Hungarian, too, and adds that the exaggerating adverbs halálban 'in death', halálra 'to death' were already attested centuries ago. Thus, there can be no objection to the metaphorical use of halálra neveti magát 'laugh oneself to death', halálra ijed 'get frightened to death', halálra/holtra válik 'be petrified, look like death'. Originally, then, halálra válik must have meant 'die (soon)'. Consequently, halálra ver counts as an idiom in which halálra is a verbal modifier. The same can be said of félholtra ver 'beat half-dead', kékre-zöldre ver 'beat blue and green', véresre ver 'beat sy until he bleeds', in the same way as the adverbial component of agyon|ver 'beat dead' used to be an idiom chunk. But halálra preserves more of its original meaning, its motivatedness, hence it has less chance to be grammaticalised than agyon whose root underwent a semantic change 'head' $\rightarrow$ 'brain' and whose original meaning was thus overshadowed to some extent. It is of course mainly in expressions at least partly preserving the original interpretation 'on the head' $\rightarrow$ 'to death' that agyon can be replaced by halálra: in expressions with the secondary meaning 'too much', this is difficult to accept: *halálra igekötözött 'preverbed to death', *halálra szoláriumozott 'tanned to death'. On the other hand, there are forms that show a 'very' interpretation: halálra röhögi magát 'laugh a lot' (also, as a slang expression: hullára röhögi magát (lit.: 'laugh oneself into a corpse')), halálra keresi magát 'earn a tremendous sum of money', halálra unja magát 'be bored stiff', etc. In the Magyar Hírlap database, I have found an example in which halálra is beginning to assume the metaphorical meaning 'too much' of agyon:

Clinton a múltkoriban keserüen panaszkodott, hogy a republikánusok megállítják, lelassítják, megölik vagy egyszerüen csak halálra beszélik a törvényhozásban a reformjait. . (Magyar Hírlap, 7 November 1994, 7)

'Clinton bitterly complained the other day that Republicans stop, slow down, kill his reforms, or simply talk them to death in the legislative assembly.' 
(18) tönkrejut 'fail'/'go broke', tönkremegy 'get spoiled'/'go broke', tönkresilányít 'mar', tönkretesz 'spoil, bring to ruin', tönkrever 'defeat totally', tönkrezúz 'shatter'

As can be seen, it is no wonder so many commentators wish to exclude tönkre- from among preverbs, calling it a mere compound constituent. If we take into consideration the facts that tönkre|jut is practically obsolete and tönkre|silányit is stylistically labelled as 'informal' in the dictionary, we are left with four verbs only, making the productivity of the pattern dubitable. But as we have seen in connection with agyon-, the dictionary and everyday usage may show considerable divergence (the recent revised edition of ÉKSz., Pusztai 2003, only contains 27 entries in agyon-). Therefore, I have gleaned all occurrences of tönkre- from the Magyar Hirlap corpus, with the following results. In the issues from 1994-2001 of that newspaper, one and a half times as many occurrences (2955) can be found as with agyon-, but whereas the two thousand or so tokens of the latter are distributed over 208 types (verbs and participles), the item tönkre- occurred in only 18 different verbs. These are as follows:

(19) tönkre|ázik 'get drenched', -bombáz 'bomb', -cenzúráz 'censor', -fut 'run', -gyakorol 'exercise', -lapoz 'thumb (a book)', -lő 'shoot', -megy 'go', -nyom 'crush', -nyúz 'exploit', -privatizál 'privatise', -silányít 'mar', -simogat 'stroke', -tesz 'make', -tol 'push', -vág 'cut', -ver 'beat', -zúz 'shatter'

The loadedness of two of these stands out strikingly: tönkretesz 'spoil' and its derivatives occur 1184 times, and tönkremegy 'get spoiled/go broke' and its derivatives occur 1089 times, whereas the remaining 692 tokens are distributed over 16 types. Of the latter, some are really recent:

(20) Lady Menuhin nem mindennapi egyéniségének jelentős szerepe volt abban, hogy nem hullott szét a férje világa, amikor kiderült: a mester hosszú pályafutása alatt tönkregyakorolta az ujjait, és ezek már nem mindig engedelmeskednek a koncertek során.

(Magyar Hírlap, 20 April 1996, 14)

'Lady Menuhin's remarkable personality played an important role in preventing her husband's world from falling to pieces when it turned out that the Maestro, during his long career, had ruined his fingers in practising so that they did not always obey him during his concerts.'

(21) Az etióp Főnök — társai csak így, azaz Neftengának szólítják - egyszerüen tönkrefutotta a hajrában az ugyancsak csúcsra áhítozó kenyai Daniel Koment.

(Magyar Hírlap, 15 August 1997, 19)

Acta Linguistica Hungarica 51, 2004 
'The Ethiopian Boss - his team-mates only call him that, i.e., Neftenga - in the finish simply sprinted to rout the Kenyan Daniel Komen who had also aspired to break the record.'

(22) ... sok család vásárol az ünnep elött tapsifülest — meggondolatlanul és feleslegesen. Napok alatt megunják az állatot, s még az a jobbik eset, ha elviszik az állatkertbe. Itt nyomban kiderül, hogy szó szerint tönkresimogatták, dédelgették, nyomorgatták az állatokat. (Magyar Hírlap, 14 April 2001, 20) ${ }^{15}$

'Many families buy bunnies before Easter - heedlessly and needlessly. They lose interest in the little animals in a few days, and it is the better of the two possibilities if they take them to the Zoo. It usually turns out there that the animals were literally caressed, fondled, fingered to the brink of ruin.'

(23) A gyorsan feledésbe merült beatkorszak atmoszférája, darabos lendülete annyira eleven a kötetben, hogy az olvasó riadtan keresi az azóta eltűnt bisztrókat, zenei élményeket, a szabad szombat összehasonlíthatatlan izgalmát - a kor egész jól működő, már tönkreprivatizált „infrastruktúráját”.

(Magyar Hírlap, 12 August 1995, 5)

'The atmosphere of the fast forgotten Beat Age, its rough vigour comes through so lively in the book that the alarmed reader will start looking for the snack bars and musical experiences that have disappeared since, the incomparable excitement of Saturdays off - the whole "infrastructure" of the period that worked rather smoothly but that has already been privatised to ruins.'

As regards the loadedness of tönkre in Vasárnapi Újság, the emerging picture is interesting there, too: only tönkrejut 'fail'/'go broke', tönkrejuttat 'ruin', tönkretesz 'spoil, ruin', and tönkrever 'defeat totally' occur spelt solid, but tönkre jut is spelt as two words 18 times and only 9 times as a single word, tönkre ver occurs in 37 cases whereas tönkrever only once, and 37 instances of tönkre tesz occur as against 5 tokens of tönkretesz. Other forms that occur as phrases are tönkre megy 'be damaged', tönkre silányít 'mar', tönkre silányul 'be marred', and tönkre rongál 'destroy' (all four occurring once). In sum: not only was tönkre a lot less frequent at that time than agyon, but it also appears to have been more independent, semantically more motivated: it was written as a separate word in a preverbal position relatively more often than agyon. That is: tönkre was simply an idiom chunk at the time, very much at the beginning of its way to becoming a preverb. But the fact that the process had started

${ }^{15}$ Cf. agyonsimogat 'caress to death' that can be taken literally or metaphorically, as opposed to tönkresimogat that may not imply actual killing by caressing. 
is nevertheless shown by its relative productivity: as opposed to other idiom chunks whose distribution is rather limited (like férjhez (megy/ad) 'get married/marry off', lit.: '(go/give) to husband', fejet (hajt) 'resign oneself to sg', lit.: '(bow the) head'), tönkre occurred in 8 combinations, and indeed some prototypical meaning 'to a useless, valueless condition' began to take shape, while the same is not true of the examples just given.

All in all, we can say that - even if they are far from those of agyonthe patterns of combination involving the preverb tönkre can be seen as productive. It seems to be well-founded, then, that Kiefer and Ladányi classify this item as a preverb, in contradiction to the earlier literature.

On the other hand, some open questions remain. First, if productivity is a major criterion for them, why do we not find the preverb haza'home' in their list? It is true that Soltész (1959) also says that, even though this item is productive, it cannot be one of the preverbs because of its straight semantics (see above). In addition, Kiefer and Ladányi base their list primarily on that of Temesi (1961), and since the latter does not discuss haza- among the preverbs, they do not, either. But Szemere (1965), ÉrtSz., and Jakab (1976) do treat this item as a preverb, therefore Kiefer-Ladányi (2000) should at least consider the issue. The more so since ÉrtSz. itself contains 38 items involving haza:

(24) haza|ad 'give', -beszél 'speak', -bocsát 'let go', -enged 'id.', -ereszt 'id.', -ér 'arrive', -gondol 'think', -hív 'invite', -hoz 'bring', -húz 'pull', -jár 'keep going', -járó 'often going', -jön 'come', -jövet 'on one's way', -jut 'get', -kéredzik 'ask permission to go', -kéredzkedik 'id.', -kísér 'escort', -kívánkozik 'wish to go', -küld 'send', -megy 'go', -néz 'look', -rendel 'order to come', -szalad 'run', -száll 'fly', -szállít 'transport', -szivárog 'ooze', -szólít 'call', -szökik 'escape', -takarodik 'take oneself off', -talál 'find one's way', -telepít 'resettle', -tér 'return', -utazik 'travel', -vágyik 'long to go', -vár 'expect', -vergődik 'go with difficulty', -vet 'throw', -vezet 'lead', -visz 'take'

Searching the Magyar Hirlap material again, we find 91 more verbs involving the preverb haza-. These will not be listed here but it is quite clear that the paradigm of this item is also productive, especially with certain prototypical verbal heads of the 'go', 'transport', 'call', 'send', and 'speak' type. Let us just take the last type as an example: haza|üzen 'send a message home', haza|telefonál 'phone home' are attested, but haza|emilezik 'email home' or haza|esemesezik 'send an SMS home' are just as acceptable. In the sense 'take some vehicle home', too, various names of means of transport can be productively used. Attested forms include haza|autókázik 'take a car home/drive home' and haza|taxizik 
'take a cab home', but equally possible forms are haza|villamosozik 'take a tram home', haza|trolizik 'take a trolley bus home', haza|tujázik 'take (the outside of) a tram home', or even haza|rollerozik 'scooter home' or haza|inlineskatezik 'use an in-line skate to get home'.

Consider a specific instance that excellently proves the productivity of the pattern (the general meaning could be roughly paraphrased as 'refer to one's own people in a given manner'):

(25) Nem kell a duma a gazdasági alapokról, a gazdálkodásról, a fejlődésről, tulajdonról. Nem is erről van szó, ugye. Hanem hogy a beste zsidajai elveszik a Fradit. Mellékesen sportügy ez, merthogy a nemzeti jelképet nyúlják le. Egyenes beszéd, végre. A múlt hét végén még volt némi bizonytalankodás, kommentárokban tanakodtak, vajon hogyan szurkolnak majd a Fradinak a B-közép ifjai. Most már azonban feltehetik a kérdést egyenesen is, minden fakszni nélkül: ezentúl hogyan lehet zsidózni majd? Holott szerintem zavartalanul. Úgy, mint rég. Legfeljebb kissé önkritikusan. Időnként hazazsidóznak majd.

(Magyar Hírlap, 26 July 2001, 7)

'Cut the crap about financial bases, economy, development, property. That's not the point. But that those beastly Jews take our sports club away. This is only incidentally a matter of sport: it is a national symbol that they dip. Straight words, at last. At the end of last week there still was some uncertainty, commentaries were pondering over how, from now on, the youngsters of the hard core would support their team. But now, the question can be asked straight away, with no fuss: how can they abuse Jews from now on? Well, in perfect tranquillity. Just like before. At most, a bit more self-critically. Sometimes they will do a little self-abuse of Jews ["Jew home"].'

Forms like haza|komcsizik 'bolshie home', haza|cigányoz 'Gipsy home', haza|nácizik 'Nazi home' could be composed in the same way. ${ }^{16}$

Another problem with Kiefer and Ladányi's classification is that, among the items they discarded, felül- 'over-' does appear productive in light of our corpus search, and even the preverbs helyre- 're-', közbe-

${ }^{16}$ In addition to the pieces of literature referred to above, NyKk. (Grétsy - Kovalovszky 1980-1985, I, 981) also lists haza- among the more recent preverbs of Hungarian. Given that the loss of morphological transparency has a major role in an item becoming a preverb, that development in the case of haza- may have been facilitated by its becoming an adverb relatively early on. Components of the latter change included phonological factors (the shortening of final -á, making the inflectional relation opaque), as well as the analogical levelling within the paradigm of ház 'house'. These changes had isolated haza from its own paradigm relatively early and blurred the etymological connections it used to have. 
'inter-', and tova- 'forth' may be characterised as relatively productive. ${ }^{17}$ Let us take a closer look at these, too.

The item felül- is excluded from among preverbs not only by Kiefer -Ladányi (2000), but also by Jakab $(1976,99)$. He writes about the type into which he classifies felül- that

\begin{abstract}
"the forms including them could be regarded as compounds, some of them involving semantic change, others based on simple fusion. Although their anterior constituents occur in several forms each, they have not reached the level of becoming a preverb. These compounds, then, are similar to items with an adverbial anterior constituent like jólesik (neki) 'please (sy)', jóllakik 'eat one's fill'; jóváhagy 'approve (of)', jóváír 'credit (to)', jóvátesz 'set right'; nyilvántart 'keep on file', etc."
\end{abstract}

But is this really the case with felül-, too? ÉrtSz. reckons with it as a preverb, but it contains altogether ten verbs that involve it (plus a few deverbal forms like felüljáró 'overpass', felülnézet 'bird's eye view', etc.):

(26) felül|bélyegez 'overprint', -bírál 'supervise, counter-check', -emelkedik 'rise above', -halad 'surpass', -ír 'overwrite', -kerekedik 'gain the upper hand', -múl 'surpass', -üt 'overtrump', -véleményez 're-survey', -vizsgál 're-examine'

I think a certain prototypical meaning ('transcending a former state of affairs') can be observed in these. Pusztai (2003) also treats this item as a preverb, even though labelling it "rare"; his data roughly coincide with those in ÉrtSz. However, in the Magyar Hirlap corpus, I have found 30 more of them: some of these involve participles, and two involve deverbal nouns (felülajánlás 'overbid', felülvélemény 'revaluation'), most of them, however, are finite verb forms and carry the same prototypical meaning as those in ÉrtSz., e.g., felül|áraz 'overmark the price of', -becsül 'overestimate', -fertőződik 'be infected (in addition to an earlier infection)', -licitál 'outbid', -teljesít 'overfulfil'. Wherever felül- joins a

17 The cases of ellen- 'against' and külön- 'apart' are slightly different in that they are not really productive with verbs but they are clearly so with nouns, and not only with deverbal ones at that. These forms appear to be mostly loan translations in the case of ellen-, e.g., ellenszenv 'antipathy' $(\leftarrow$ Latin antipathia), ellentengernagy 'rear admiral' ( $\leftarrow$ German Konteradmiral). The forms with külön-, on the other hand, are mostly recent analogical forms like különadó 'surtax', -akció 'separate action', -játszma 'separate game', -jövedelem 'extra income', -kereset 'extra earnings', -vagyon 'separate property', -zárka 'solitary cell', etc. This type has its own productivity but since these anterior constituents may not exclusively precede deverbal items, I would take this to be a productive pattern of compounding rather than instances of productive preverbs. 
perfect participle, the static version of the above prototypical meaning 'over(ly), in a degree transcending a former state of affairs' is witnessed: felül|dimenzionált 'over-dimensioned', -képzett 'over-trained', -világított 'over-lit', -kormányzott 'over-governed', -garantált 'over-guaranteed'. In a smaller number of instances, the original, concrete meaning of the preverb ('above') can also be found; this meaning is not given in Pusztai (2003) even though it is on the spread in specialised texts, e.g., felültöltös (mosógép) '(washing machine) to be loaded from the top', felülvezérelt 'steered from above', felülszelepelt (motor) '(engine) with valve on top'. What is more, we could not say these are all loan translations. Although felültöltös follows the English model (top loader) quite faithfully, with combustion engines this is not the case: the English equivalents are overhead camshaft (OHC) or double overhead camshaft (DOHC). Nevertheless, given that this meaning is instantiated by a mere three items, and even these have a locative (non-directional) meaning, ${ }^{18}$ they can be treated as compounds involving adverbs. As concerns the more productive meaning 'transcending a former state of affairs', however, this is more directional in flavour (e.g., felülmúl 'surpass' = fölébe kerekedik 'gain advantage over', lit.: 'get above, get into a higher position'). Thus, the relatively high number of data must make us consider whether we can really discard felül- from among preverbs (especially if the numerically less productive tönkre- is given preverb status).

The case of közbe- is also worth reconsidering. Its status is similar to that of felül-, in that ÉrtSz. contains 14 verbs with it, and Pusztai (2003) also attaches the tag "rare" to it. The ÉrtSz. data are the following:

(27) közbe|beszél 'keep interrupting', -esik 'intervene', -ékelődik 'become interpolated', -iktat 'insert', -játszik 'interfere', -jön 'occur (e.g., an unforeseen obstacle)', -kiált 'interrupt (shouting)', -lép 'intercede', -szól 'interrupt', -szúr 'insert', -told 'intercalate', -vág 'interrupt', -vegyül 'intermingle', -vet 'interpose'

In addition, 14 more of these have been found in the Magyar Hirlap database:

(28) közbe|avatkozik 'interfere', -dumál 'keep interrupting', -kérdez 'interrupt with a question', -kiabál 'interrupt (shouting)', -kotyog 'chime in (with silly remarks)', -kurjant 'interrupt (shouting)', -mormol 'mumble (while sy is talking)', -ordít 'interrupt (shouting)', -pöccintget 'keep prodding in', -rivalg(ás) 'interrupt(ion)

${ }^{18}$ Jakab $(1982,64)$ says that directional meaning is a characteristic feature of preverbs as a part of speech.

Acta Linguistica Hungarica 51, 2004 
(by cheering)', -robban 'barge in', -tapsol 'clap into (a performance or speech)', -üt(és) 'join(ing) in with a blow', -zár 'flank'19

Of these, we have to isolate közbezár, in which the meaning of the adverbial element differs from 'interrupting some process' that the others seem to share prototypically, and can be paraphrased roughly as 'demarcate with lines (on both sides)'. Since no other data can be found with this meaning, I think this pattern is not productive and közbezár can be seen as an adverb-initial compound. For the rest of the examples, however, the meaning 'interrupt some action or process by doing something (especially by some verbal utterance or by creating some sound effect)' can be seen as prototypical. Consider the following two examples from Magyar Hirlap, as well as a list of potential forms that have not been attested but would clearly be possible according to the productive pattern:

(29) Szalay mindvégig szép és pontos riposztokkal, egyenes vonalú, energikus akciókkal szerezte találatait, míg Moresse ravaszul közbepöccintgetett Gyöngyi karjára, csuklójára.

(Magyar Hírlap, 20 July 1995, 19)

'Szalay scored her hits with fine and accurate ripostes, with straight and energetic actions, whereas Moresse kept prodding in cunningly, hitting Gyöngyi's arm or wrist.'

(30) A képernyőmön megjelenik egy Polanski nevezetű válasza Oklahomából: Szia, te honnan jöttél? Valaki közbekotyog Ausztráliából, kész őrület, de John Londonból rendreutasítja. Ezt a lapot tényleg az olvasók írják.

(Magyar Hirlap, 16 August 1995, 8)

'On my screen, a reply appears from one Polanski from Oklahoma, Hi, where you from? Someone chimes in from Australia, sheer lunacy, but John from London pulls him up. This paper is really being written by the readers.'

Similarly, forms like közbe|rizsázik, -vakerol, -pofázik, -ugat, -spícsel, -gügyög, szövegel, -kotnyeleskedik (all: 'interrupt in some manner', most of them slang), or közbe|dúdol 'hum', -trillázik 'warble', -nyávog 'mew', -csivitel 'chirp', -fütyül 'whistle', -gajdol 'sing rudely', -óbégat 'yammer', or even közbe|vivátoz 'cheer into', közbe|komcsizik 'bolshie into', közbe|zsidózik 'Jew into' (somebody's speech), etc. would be conceivable.

As far as the status of helyre- is concerned, 12 forms with it can be found in ÉrtSz. (Pusztai 2003 also labels it as "rare"):

${ }^{19}$ Of these, közbeavatkozik 'interfere' is also listed in Pusztai (2003). 
(31) helyre|áll 'be restored', -állít 'restore', -hoz 'remedy', -igazít 'rectify', -jön 'recover', -megy 'go to one's place', -pofoz 'patch up', -pótol 'make up for', -tesz 'replace, put back', -ugrik 'jump into position', -üt 'patch up, save the situation', -zökken 'jump back into place, get into shape again'

All of these have a directional sense, and can be grouped around two meanings: (a) to its original/former place (concrete): helyremegy, -tesz, etc.; (b) to its original/normal state (abstract): helyreáll, -igazit, etc. The corpus yielded 14 more verbs, with meanings in these two general areas:

(32) helyre|biccent 'remedy, set right', -billen 'even out', -billent 'set right', -döngöl 'pound into place', -kalapál 'hammer into shape', -kísér 'escort back to place', -rak 'put back', -rángat 'tug to place', -rázódik 'be jolted back', -rugdal 'keep kicking back to place', -tol 'slide back to place', -tolódik 'be slid back', -utasít 'snub sy'

It is in the concrete meaning that the pattern is more productive; this is where we can easily think of further examples, especially with verbs of motion and verbs of moving something, e.g., -fut 'run', -szalad 'run', -biciklizik 'bike', -settenkedik 'sneak', -bandukol 'walk slowly', -gördeszkázik 'rollerskate', respectively -ránt 'wrench', -rúg 'kick', -sarkal 'kick with heel', -csúsztat 'slide', -bújtat 'slip', -vonszol 'drag', -nyom 'push' (all: 'back to place'). On the other hand, productive uses of the abstract meaning can also be found, e.g.:

(33) Most legalább érzi, milyen nehéz a dolgunk, nekünk, moderátoroknak. Ha rosszkor rosszat szólunk, azt már nem lehet helyrekalapálni.

(Magyar Hírlap, 22 December 2001, 28)

'Now you see at least how difficult a job we, moderators, have. If we say the wrong thing at the wrong time, it cannot be set right any more.'

(34) Nagy Sándor jónak tartaná, ha a kormány a kiadások csökkentése helyett inkább a bevételek növelésével igyekezne helyrebillenteni a költségvetést.

(Magyar Hirlap, 5 July 1995, 1)

'Mr Nagy would prefer if the government tried to balance the budget by increasing revenues rather than by curtailing public expenditure.'

Further examples with this meaning can also be created, even if with some difficulty (e.g., helyrebunkóz 'correct with a cudgel', -püföl 'by pummelling', -simogat 'by caressing', -köszörül 'by whetting'). In sum, I submit that the adverb helyre also has a place in the system of preverbs.

As concerns tova- 'forth, away', ÉrtSz. indeed only contains five verbs with that preverb: tova|halad 'proceed', -siet 'hurry on', -száll 'fly along', 
-terjed 'spread on', -tünik 'vanish from sight' and Pusztai (2003) not only labels it "rare" but also "elaborate style". On the other hand, the Magyar Hirlap corpus yields 21 more items (with 289 occurrences in all). These are as follows:

(35) tova|áramlik 'flow', -billen 'tilt', -döcög ‘wobble', -fut 'run', -gördül 'roll', -gyưrűzik 'ripple', -hagy 'leave', -hessent 'swat at', -húz 'pass', -illan 'evanesce', -nyargal 'gallop', -repül 'fly', -röppen 'flit', -siklik 'glide', -sodor 'whirl', -sodródik 'drift', -suhan 'swish', -száguld 'race', -úszik 'swim', -vádorol 'wander', -vitorlázik 'sail' (all: 'on, along, away')

The meaning of the preverb, it appears, preserves the concrete meaning of the adverb: 'further and further away'. On this basis, it can almost without restriction be coupled with motion verbs as in tova|kerekezik 'cycle', -biciklizik 'bike', -motorozik 'ride (a motorbike)', -gördeszkázik 'rollerskate', -rollerezik 'ride (a scooter)', -jetskizik 'jet ski', or tova|lebeg 'float', -reppen 'flit', etc. There is but one semantic restriction: the verb must express a movement that is (or can be) performed 'away', 'into the distance'; it cannot be circular or oscillating: *tovakering 'revolve away', *tovaperdül 'spin along', *tovahánykolódik 'be tossed forth', *tovarezeg 'oscillate away', *tovavibrál 'vibrate away', etc. On the basis of the above examples, tova- may be classified as one of the preverbs, too; although, due to the lack of an abstract meaning, they could also be referred to as adverb-initial compounds.

Is sum, I think that the results of this empirical study have proved how important it would be for productivity investigations to be based on actual corpus data. With productivity tests based on such data it has been demonstrated that felül- 'over', közbe- 'inter', helyre- 'back' (and possibly tova- 'forth') may, after all, be classified as preverbs, as is done by both ÉrtSz. and Pusztai (2003). We are entitled to do that especially since they are at least as productive as tönkre- 'to ruins' is that Kiefer and Ladányi also claim to be a preverb. True, the former items have a somewhat more concrete meaning, whereas tönkre can only be used metaphorically. That is, in this case, the criterion of semantic "opacity" or idiomatic character is more fully met (as expected due to its origin as an idiom chunk). On the other hand, helyre- and felül-also exhibit secondary, more abstract meanings, too. All in all, I think all four items under scrutiny here meet the set of criteria that Kiefer and Ladányi (2000, 481) formulate for preverbhood. That is: none of them is an argument-type verbal modifier, all of them perfectivise and all of them 
can be claimed to be productive. In addition, they meet the dynamic character (or directionality) that Jakab $(1976 ; 1982)$ insists on. Another point of Jakab's classification system is text frequency: this may be the only criterion that they do not meet - but then, Kiefer and Ladányi do not appear to take this to be crucial, either. ${ }^{20}$

\section{Conclusion}

A number of theoretical issues arise with respect to preverbs, as witnessed by Jakab (1982) where a lengthy discussion is found concerning what a number of earlier grammarians had to say about them. For want of a better solution, most authors circumvented the problem of definition and referred to the status of the given items by way of a list. Since then, a number of attempted definitions have been published but linguists are still highly divided over exactly which items should be seen as belonging to the set of preverbs. One of the reasons for that uncertainty may be the fact that we have to do with a relatively recent development - at least as compared to the time span of historical processes that languages undergo - , we are faced with a part of speech still in the making.

Another similar class is that of postpositions. They also include earlier ones that are not formally transparent any more and whose semantic transparency or motivation has also been lost due to a concrete $\rightarrow$ abstract development of their meaning (e.g., után 'after': in space $\rightarrow$ in time). Younger postpositions, on the other hand, are still rather transparent both morphologically and semantically (e.g., következtében

${ }^{20}$ On the other hand, we can agree with Kiefer and Ladányi that abba, végbe and véghez ['that-illative', 'end-illative', 'end-allative'] are to be deleted from the list of preverbs since the first two only join up with two verbs each (abbahagy 'stop doing', abbamarad 'be discontinued'; végbemegy 'take place', végbevisz 'carry out', cf. hagy 'leave', marad 'remain', megy 'go', visz 'carry') and the third is used with a single verb only (véghezvisz 'accomplish'). These, then, are lexicalised complex verbs and not preverb+verb combinations. The status of félbe- ['half-illative'] is a real borderline case: the combination patterns of that item are less productive than those discussed in the text. ÉrtSz. contains four verbs with it: félbehagy 'stop doing', félbemarad 'be discontinued', félbeszakad 'be cut short', félbeszakit 'break sg off' (cf. szakad 'be torn', szakit 'tear') and only a few further examples can be found in the Magyar Hirlap corpus, too: félbehajt 'fold in two', -hajtódik 'be folded in two', -harap 'bite into two', -metsz 'cut into two', -tör 'break into two', -vág 'cut into two'. In these, a strong adverbial meaning can be detected, so much so that some of these could even be spelt as two words. 
'in consequence of'). Also, the set of postpositions is partially open: further items may additionally start turning into postpositions: an instance is magasságában 'at the altitude of' in the still somewhat mannered temporal sense 'around, at roughly'.

The same can be said of preverbs. In the ancient members of the class, their morphological transparency has totally ceased to exist; but even relatively younger ones like those going back to postpositions include non-transparent items (like keresztül 'across', túl 'over'). Other - especially younger - items may still have a transparent morphological structure (e.g., újra 'again, lit.: new-sublative', végig 'fully, to the end, lit.: end-terminative'). This set is partially open, too. Thus, it is impossible to predict whether halálra 'to death' will become even more widespread than it is today, becoming a proper preverb. This is because it has already grown out of the role of a mere idiom chunk: it can join a relatively large number of verbs whereas real idiom chunks can only join one or two. Of course, this process can be affected by the influence of other languages, too: recall the case of ellen- 'counter' often joining nominal (rather than verbal) bases or the expression felültöltös (mosógép) 'top loader'.

It appears that wherever morphological transparency has not been totally lost, semantic non-transparency can be attested instead in most cases. This applies especially clearly to agyon- and tönkre-, both going back to idiom chunks. In the former case, the meaning of the stem has undergone a change (agy 'skull' $\rightarrow$ 'brain'), whereas in the latter case the relevant meaning of the stem is not quite clear for language users (tönk 'a stump in water' or 'wood-cutting block in the yard'). Even if semantic transparency is also maintained, an adverb may still turn into a preverb. It is enough for its meaning to become minimally more abstract; what is required is that productive patterns of association should come into being. It is on the basis of such productivity considerations that verbs involving tovább- 'on', végig- 'to the end', or újra- 'again' can be seen as preverb+verb combinations.

It appears that directional meaning is another important factor of being a preverb: ${ }^{21}$ there are hardly any non-directional preverbs in Hun-

${ }^{21}$ Agyon with its superessive inflection seemingly contradicts this generalisation, but it is in fact at least partly directional in meaning: the very literal/original meaning of agyonvág 'hit on the head' can be paraphrased as fejen vág ('headsuperessive + hit') but rather as fejbevág ('head-illative + hit'). In addition, agyon later underwent semantic change and assumed a perfectivising, or rather exaggerative function as in agyonbeszél 'talk too much about' or agyonhallgat 'kill by silence'. 
garian. What the reason for that may be is surely a very complex issue but it is possible that cognitive factors also play a role. As Pléh (2000, 1010) points out, "in human thinking, aims/targets are in the forefront. The appearance of TARGET in spatial expressions in fact reflects the organisation of an intentional act, a cognitive preference".

As in the case of all other linguistic items, it may also occur in the historical development of preverbs that some of them stop short before evolving into a full preverb: the adverbial element becomes dated, or mannered. This is what happened to által 'through, by (means of)' that has been supplanted both as a postposition and as a preverb-like anterior constituent by the shorter, hence more economical version át 'through, across, over' (as a postposition only in a local or a temporal sense). ÉrtSz. still considers it to be a preverb, and lists 18 verbs involving it (által|ad 'hand over', - cikázik 'flash across', - esik 'fall through'/ 'get over with', -fog 'clasp', -hajt 'drive through', -hat 'imbue', -hág 'infringe', -jár 'go across (frequently)'/'permeate', -lát 'see across', -lép 'step over', -megy 'go over', -nyújt 'hand over', -önt 'pour over', -üt 'show through'/'hit across', -vág 'cut through', -ver 'pierce', -vesz 'take over', -vet 'sling over'). In the Vasárnapi Újság corpus, I found 18 more verbs (által|cserél 'change over', -él 'experience', -enged 'relinquish', -ereszt 'let (pass) through', -érez 'be aware of', -hoz 'bring over', -jön 'come over, come through', -karol 'embrace', -szivárog 'ooze through', -szúr 'stab (through)'). On the contrary, Pusztai (2003) already labels általas "rural" and "obsolete", and lists only 3 verbs with it (által|jár, -lép, -megy). In the Magyar Hirlap corpus, too, only six such items can be found, two of them in citations from 19th-century texts. The real number, then, is four. If we consider token frequency, these forms also turn out to be rather rare: all four occur but once in the Magyar Hirlap corpus, and even in Vasárnapi Újság, all verbs occurred once except által|ad 'hand over' with 23 occurrences. ${ }^{22}$

\footnotetext{
${ }^{22}$ These numbers refer to preverbs in preverbal position: since által is found on its own 3102 times in the corpus but most of the time as a postposition, I have not individually checked all the data where it stands alone to see whether there are some preverbs (split from their verbs) among them. It is to be noted furthermore that the preverb egybe 'together, into one' has had a somewhat similar progress: it showed fusion patterns with a number of verbs already in the age of codices, ÉrtSz. lists 44 such preverb-verb combinations, and Magyar Hirlap contains a lot more. Therefore, it is in fact difficult to see why Kiefer and Ladányi omit it from among Hungarian preverbs, as it is listed as such in Jakab (1982). It is, however, beyond reasonable doubt that egybe is in retreat today in that össze 'together' will/may oust it analogically from a number of combinations.
} 
As far as the size of the stock of Hungarian preverbs is concerned, Pais (1959) already states that the difference between an adverb and a preverb is not so much that of kind, rather that of degree. Hence, rather than debating whether a given item has already turned into a preverb or is still an adverb, it is more expedient to employ the "centre vs. periphery" model of the Prague School. Thus, there are preverbs that are in a fully central position, including the "ancient" preverbs, especially $m e g$ - that was originally a directional adverb 'to behind' just like be- 'in', $k i$ - 'out', le- 'down', and fel- 'up', but has practically completely lost its directional meaning ('to behind it' $\rightarrow$ 'back'), and is used to express metaphorical meanings (mainly perfectivity) today. Right after meg-, the next most central preverb is el- that still retains its meaning 'away' but its perfective or inchoative function is a lot stronger. The next concentric circle would be where the four preverbs of ancient origin referred to above are located: these express direction as well as various metaphorical meanings. An even less central circle would be where later items that have preserved more of their adverbial meaning and character like hátra- 'to the back', félre- 'to the side', körül- 'round', ide- 'here', oda- 'there', szét'apart', össze- 'together', as well as those going back to postpositions: alá- 'to under', elé- 'to the front', fölé- 'to above', mellé- 'to beside', át'through', keresztül- 'across', túl- 'beyond' are found. These are bulkier than the items on the inner circles, they preserve their individuality more than those, but their morphological transparency has been lost, facilitating their changes in terms of parts of speech: case-marked noun $\rightarrow$ adverb $\rightarrow$ preverb (/postposition). Another, more peripheral circle is occupied by agyon- 'over, to death' and tönkre- 'over, to ruins' that started their careers as idiom chunks, and are morphologically transparent but semantically less so (due to the semantic change, respectively vagueness, of their stems - see above). An even more peripheral set comprises adverb-based újra- 'again', tovább- 'further on', végig- 'to the end' that are both morphologically and semantically transparent and can only be taken to be preverbs due to their frequent occurrence and productivity. The outermost circles are occupied by items of debated status, ones that certain grammars take to be preverbs while others do not. The more peripheral a given item is in this system, the larger share productivity has in the definition of its status: if it can turn into a fully productive pattern as time goes by, its way is open towards increasingly inner circles. For instance, újra 'again', lit. 'new-sublative' is both morphologically and semantically quite transparent and only occurs in 8 verbs in ÉrtSz. but it 
shows a remarkably productive pattern in the Magyar Hirlap database, of which only some very recent items will be listed here to finish with: újrabootol 'reboot', újrair 'rewrite', újranyomtat 'reprint', újrakábelez 'rewire', újratemet 'rebury', újraprivatizál 're-privatise', újraéleszt 'revive, resuscitate', etc.

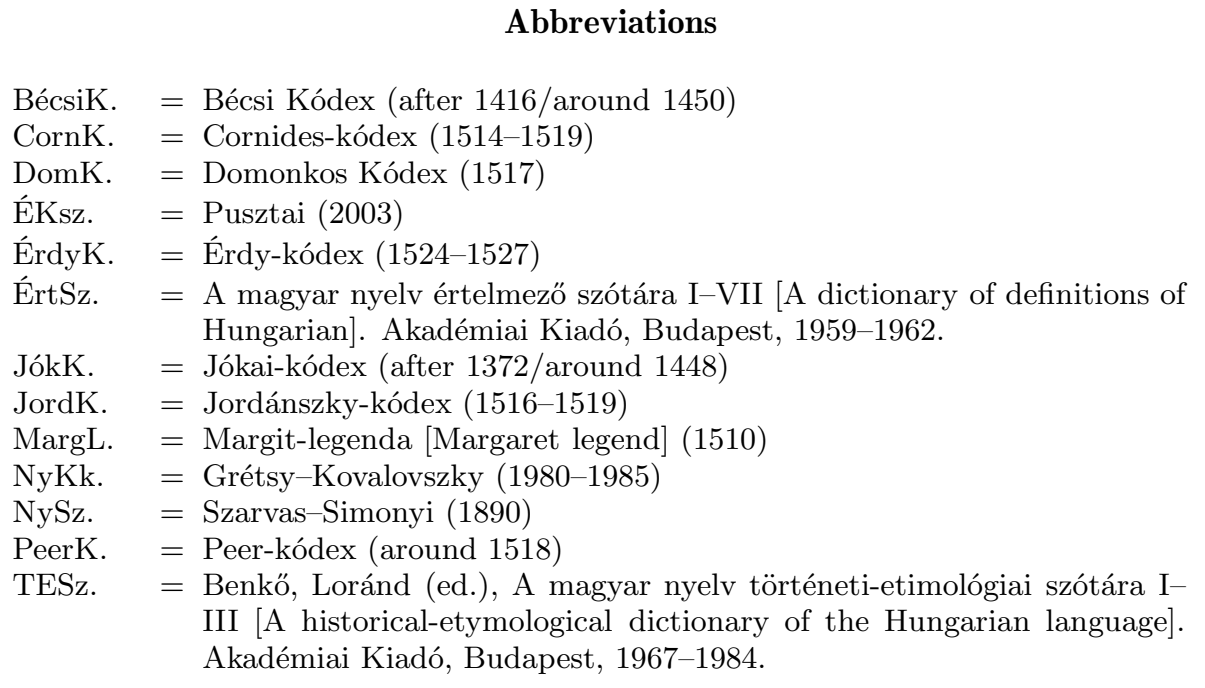

\section{References}

Deme, László 1959. A nyomatéktalan mondat egy fajtájáról. Az ott határozószó igekötőszerü használata [On one type of non-emphatic sentences. The preverb-like use of the adverb ott 'there']. In: Magyar Nyelv 55 : 185-98.

É. Kiss, Katalin 1998. Mondattan [Syntax]. In: Katalin É. Kiss-Ferenc Kiefer-Péter Siptár: Új magyar nyelvtan [A new Hungarian grammar]. 15-184. Osiris Kiadó, Budapest.

Fleischer, Wolfgang 1997. Phraseologie der deutschen Gegenwartssprache 2., durchgesehene und ergänzte Auflage. Niemeyer, Tübingen.

Grétsy, László - Miklós Kovalovszky (eds) 1980-1985. Nyelvművelő kézikönyv I-II [A handbook of language cultivation I- II]. Akadémiai Kiadó, Budapest.

Jakab, István 1976. A magyar igekötők állományi vizsgálata [A study of the stock of Hungarian preverbs] (Nyelvtudományi Értekezések 91). Akadémiai Kiadó, Budapest.

Jakab, István 1982. A magyar igekötő szófajtani útja [The development of Hungarian preverbs among parts of speech] (Nyelvtudományi Értekezések 112). Akadémiai Kiadó, Budapest.

Acta Linguistica Hungarica 51, 2004 
Kiefer, Ferenc (ed.) 2000. Strukturális magyar nyelvtan 3. Morfológia [A structural grammar of Hungarian 3. Morphology]. Akadémiai Kiadó, Budapest.

Kiefer, Ferenc-Mária Ladányi 2000. Az igekötők [Preverbs]. In: Kiefer (2000, 453518).

Klemm, Antal 1928. Magyar történeti mondattan I [A historical syntax of Hungarian I]. Pécsi Egyetemi Könyvkiadó és Nyomda, Budapest.

Komlósy, András 1992. Régensek és vonzatok [Valence and government]. In: Ferenc Kiefer (ed.): Strukturális magyar nyelvtan 1. Mondattan [A structural grammar of Hungarian 1. Syntax], 299-527. Akadémiai Kiadó, Budapest.

Langacker, Ronald W. 1977. Syntactic reanalysis. In: Charles N. Li (ed.): Mechanisms of syntactic change, 57-139. University of Texas Press, Austin.

Mátai, Mária D. 1992. Az igekötők [Preverbs]. In: Loránd Benkő-Erzsébet E. Abaffy (eds): A magyar nyelv történeti nyelvtana. 2/1. kötet: A kései ómagyar kor: morfematika [A historical grammar of Hungarian. Volume 2/1: Late Old Hungarian: morphematics], 662-95. Akadémiai Kiadó, Budapest.

Pais, Dezső 1959. Az igekötők mivoltához és keletkezéséhez [On the status and origin of preverbs]. In: Magyar Nyelv 55 :181-4.

Pléh, Csaba 2000. A magyar morfológia pszicholingvisztikai aspektusai [Psycholinguistic aspects of Hungarian morphology]. In: Kiefer (2000, 951-1020).

Pusztai, Ferenc (ed.) 2003. Magyar értelmező kéziszótár. 2. átdolgozott és bővített kiadás [A concise dictionary of definitions of Hungarian. 2nd, revised and enlarged edition]. Akadémiai Kiadó, Budapest.

Sebestyén, Árpád 1965. A magyar nyelv névutórendszere [The system of postpositions in Hungarian]. Akadémiai Kiadó, Budapest.

Soltész, Katalin J. 1959. Az ősi magyar igekötők [Hungarian preverbs of an ancient origin]. Akadémiai Kiadó, Budapest.

Somhegyi, Gyula 1988. Monofrazémák a magyarban I. Valódi monofrazémák [Monophrasemes in Hungarian I. Monophrasemes proper]. In: Magyar Nyelvőr 112: 357-68.

Somhegyi, Gyula 1992. Monofrazémák a magyarban II. Ál-monofrazémák [Monophrasemes in Hungarian II. Pseudo-monophrasemes]. In: Magyar Nyelvőr 116 : 437-48.

Szarvas, Gábor-Zsigmond Simonyi (eds) 1890. Magyar nyelvtörténeti szótár a legrégibb nyelvemlékektől a nyelvújításig I. [A historical dictionary of Hungarian from the earliest records until the time of language reform I]. Hornyánszky Viktor Akadémiai Könyvkereskedése, Budapest.

Szemere, Gyula 1965. Helyesírási segédkönyv a középiskolák számára [A spelling manual for secondary schools]. Tankönyvkiadó, Budapest.

Temesi, Mihály 1961. Az igekötők [Preverbs]. In: József Tompa (ed.): A mai magyar nyelv rendszere I [The system of present-day Hungarian I], 263-7. Akadémiai Kiadó, Budapest. 
Address of the author: Tamás Forgács

Department of Hungarian Language

and Literature

University of Szeged

Szeged, Egyetem u. 2.

H-6722 Hungary

forgacs@hung.u-szeged.hu 